\title{
HUBUNGAN PRAKTIK PERSONAL HYGIENE PEDAGANG DENGAN KEBERADAAN BAKTERI ESCHERICHIA COLI DALAM JAJANAN KUE LAPIS DI PASAR KEMBANG KOTA SURABAYA
}

\author{
Correlation of Sellers Personal Hygiene with the Presence of Escherichia coli in Traditional \\ Layer Cake at Pasar Kembang Surabaya
}

\author{
Ardini Debilauralita Nuraya ${ }^{1}$, Triska Susila Nindya ${ }^{2}$ \\ ${ }^{1}$ Program Studi S1 Kesehatan Masyarakat, Fakultas Kesehatan Masyarakat, Universitas Airlangga, Surabaya \\ ${ }^{2}$ Departemen Gizi Kesehatan, Fakultas Kesehatan Masyarakat, Universitas Airlangga, Surabaya \\ Email: ardenaya@gmail.com
}

\begin{abstract}
ABSTRAK
Bakteri Escherichia coli yang bersifat patogen dapat mengganggu kesehatan. Adanya bakteri menjadikan jajanan tidak aman untuk dikonsumsi. Praktik personal hygiene pedagang dapat berpotensi menjadi jalan masuk bakteri Escherichia coli pada jajanan yang dijual. Penelitian cross-sectional ini bertujuan untuk menganalisis hubungan antara praktik personal hygiene pedagang dengan keberadaan bakteri Escherichia coli pada jajanan kue lapis. Penelitian ini melibatkan 29 pedagang jajanan kue lapis di Pasar Kembang Kota Surabaya. Pengumpulan data dilakukan dengan menggunakan lembar observasi dan uji laboratorium pada sampel jajanan kue lapis. Data dianalisis menggunakan uji statistik Chi-Square. Hasil penelitian ini menunjukkan sebagian besar pedagang mencuci tangan sebelum menjamah makanan (96,6\%), kuku tangan dalam keadaan bersih dan pendek $(86,2 \%)$ dan tidak merokok pada saat menjamah makanan (82,8\%). Seluruh pedagang menggunakan pakaian bersih (100\%) namun berbicara saat menjamah makanan (100\%), tidak menggunakan celemek dan alat bantu saat menjamah makanan (100\%). Bakteri Escherichia coli ditemukan pada 44,8\% kue lapis yang diuji. Penelitian ini menunjukkan tidak ada hubungan antara perilaku personal hygiene pedagang dengan keberadaan bakteri Escherichia coli pada jajanan kue lapis (p > 0,05) di Pasar Kembang Kota Surabaya.
\end{abstract}

Kata kunci: escherichia coli, kue lapis, praktik personal hygiene

\section{ABSTRACT}

Pathogenic effect of Escherichia coli bacteria could be detrimental to health. The presence of the bacteria makes food unsafe to consumed. Personal hygiene practice of sellers can influence the presence of Escherichia coli on food. This cross-sectional study was aimed to analyze the relationship between personal hygiene practice of sellers with the presence of Escherichia coli bacteria on a traditional layer cake. The study involved 29 traditional layer cake sellers in Pasar Kembang Surabaya. The data collection was done by using observation sheet and laboratory tests on samples of traditional layer cakes. Data was analyzed using chi-square statistical test. The results of this study showed the majority of sellers washed their hands before handling food (96.6\%), fingernails were clean and short (86.2\%) and didn't smoke when handling food (82.8\%). All sellers used clean clothes (100\%), but talked when handling food (100\%), did not wear an apron and tools when handling food (100\%). Escherichia coli was found in $44.8 \%$ samples. This study showed there was no relationship between personal hygiene practices of sellers with the presence of Escherichia coli bacteria in traditional layer cakes $(p>0.05)$ in Pasar Kembang.

Keywords: escherichia coli, traditional layer cake, personal hygiene practice

\section{PENDAHULUAN}

Makanan jajanan tradisional merupakan warisan budaya yang cukup diminati. Menurut Food and Agriculture Organization (2009), jajanan merupakan makanan dan minuman yang dipersiapkan dan dijual oleh pedagang kaki lima di jalanan dan tempat keramaian umum lainnya yang langsung dikonsumsi tanpa pengolahan dan persiapan semestinya. 
Makanan jajanan yang dijajakan di pasar tradisional beraneka ragam, salah satunya yaitu kue lapis. Kue lapis merupakan salah satu jenis makanan jajanan tradisional yang dikenal dan beredar di lingkungan masyarakat. Pasar Kembang yang dinaungi Perusahaan Daerah Pasar Surya merupakan pasar yang menjadi pusat grosir makanan jajanan tradisional sehingga jumlah jajanan, termasuk kue lapis, yang terjual per hari cukup besar.

Keracunan makanan dapat disebabkan oleh bakteri patogen. Salah satunya adalah Escherichia coli yang dapat menyebabkan penyakit baik berupa diare ataupun penyakit lain di luar saluran pencernaan (CDC, 2016).

Pada Bulan Januari hingga Maret 2015, di Indonesia terjadi kasus keracunan akibat pangan yang disebabkan oleh pangan jajanan sebanyak 5 insiden keracunan dengan jumlah korban sebanyak 281 orang. Pada bulan April hingga Juni 2015, sebanyak 8 insiden keracunan makanan akibat pangan jajanan dengan jumlah korban sebanyak 379 orang (Badan Pengawasan Obat dan Makanan, 2015).

Praktik personal hygiene pedagang jajanan kue lapis dapat berpengaruh terhadap kontaminasi makanan. Praktik personal hygiene sederhana seperti mencuci tangan perlu untuk ditingkatkan karena membawa pengaruh yang cukup besar dalam mengurangi keberadaan cemaran biologis yang terdapat pada makanan. Berdasarkan Latudi (2012), sebanyak 78,6\% penjamah makanan tidak mencuci tangan terlebih dahulu sebelum menjamah makanan dan setelah keluar dari kamar kecil. Kebersihan penjamah makanan memiliki hubungan dengan kandungan bakteri Escherichia coli. Menurut Mohede dan Saptorini (2015), terdapat hubungan antara hygiene pedagang dengan keberadaan bakteri Escherichia coli pada sambal makanan. Risiko keberadaan bakteri Escherichia coli 14 kali lebih besar pada penjamah makanan yang tingkat kebersihan tidak memenuhi syarat dibandingkan dengan penjamah makanan yang memenuhi syarat (Riyanto dan Abdillah, 2012).

Berdasarkan hal tersebut, penelitian ini dilakukan untuk mengidentifikasi karakteristik dan praktik personal hygiene pedagang jajanan kue lapis di Pasar Kembang Kota Surabaya, mengidentifikasi keberadaan bakteri Escherichia coli dalam jajanan kue lapis serta menganalisis hubungan antara praktik personal hygiene dan keberadaan bakteri Escherichia coli pada jajanan kue lapis yang dijual.

\section{METODE}

Penelitian ini merupakan penelitian analitik observasional dengan rancangan studi cross sectional. Populasi penelitian ini merupakan pedagang jajanan kue lapis di Pasar Kembang Kota Surabaya. Sampel penelitian adalah seluruh pedagang jajanan kue lapis yang memenuhi kriteria inklusi penelitian yaitu pedagang yang menjual langsung jajanan kue lapis dan bersedia menjadi subyek penelitian sehingga didapatkan 29 sampel. Variabel bebas penelitian adalah praktik personal hygiene pedagang jajanan kue lapis. Variabel terikat penelitian adalah keberadaan bakteri Escherichia coli dalam jajanan kue lapis. Penelitian ini telah mendapatkan persetujuan dari Komisi Etik Penelitian Kesehatan Fakultas Kesehatan Masyarakat Universitas Airlangga.

Pedagang jajanan kue lapis akan dibacakan lembar persetujuan dan ditanyakan kesediaan sebagai responden kemudian diminta mengisi lembar informed consent. Pedagang yang bersedia menjadi responden diobservasi dengan menggunakan lembar observasi dimana akan dinilai perilaku personal hygiene seperti mencuci tangan sebelum menjamah makanan, kuku tangan bersih dan pendek, menggunakan pakaian bersih, menggunakan celemek saat menjamah makanan, tidak berbicara saat menjamah makanan, tidak merokok saat menjamah makanan, menggunakan alat bantu menjamah makanan, dan tidak menggunakan perhiasan terutama cincin dan gelang. Kategori penilaian lembar observasi dibagi menjadi tiga yaitu baik dengan nilai $\geq 7$, sedang dengan nilai 4-6, dan kurang dengan nilai 0-3.

Jajanan kue lapis yang digunakan sebagai sampel diambil dengan menggunakan sarung tangan dan diletakkan dalam wadah steril dengan suhu $<4^{\circ} \mathrm{C}$. Jarak waktu antara pengambilan sampel dengan pemeriksaan kurang dari 2 jam. Pemeriksaan keberadaan bakteri Escherichia coli pada jajanan kue lapis menggunakan 
metode kualitatif yaitu uji Brilliant Green Bile Broth (BGBB), uji Eosine Methylene Blue Agar (EMBA), dan uji indol. Indikator adanya bakteri Escherichia coli pada uji BGBB yaitu warna akan menjadi hijau keruh dan terdapat gas, pada uji EMBA yaitu terdapat lendir dan permukaan media berwarna hijau metalik, dan pada uji indol akan muncul cincin berwarna merah muda. Analisis data mengggunakan uji Chi-Square yang menguji ada atau tidak hubungan antara praktik personal hygiene pedagang kue lapis dengan keberadaan bakteri Escherichia coli pada jajanan kue lapis yang dijual.

\section{HASIL DAN PEMBAHASAN}

Dalam penelitian ini diperoleh 29 subjek penelitian yang seluruhnya memenuhi kriteria sebagai responden, Responden paling banyak berjenis kelamin perempuan $(72,4 \%)$. Hasil penelitian ini sesuai dengan penelitian yang dilakukan Makalew (2013) yang menyatakan bahwa penjamah kue di Pasar Sentral Kota Gorontalo sebagian besar merupakan perempuan (90\%) dan sisanya merupakan laki-laki (10\%).

Golongan umur responden terbesar pada kategori 36-45 tahun $(69,0 \%)$ Responden memiliki tingkat pendidikan terbanyak yaitu tingkat pendidikan tinggi atau $\geq$ SMA $(51,7 \%)$. Menurut Notoatmodjo (2011), pendidikan adalah upaya persuasi atau pembelajaran agar masyarakat melakukan praktik untuk memelihara dan meningkatkan kesehatannya. Tingkat pendidikan yang cukup tinggi diharapkan dapat meningkatkan kesadaran dan memanfaatkan pengetahuan terhadap praktik personal hygiene.

Seluruh responden tidak memiliki sertifikasi penjamah makanan. Sertifikasi tersebut dapat diperoleh setelah mendapatkan kursus atau pelatihan higiene dan sanitasi makanan dengan materi yang telah ditetapkan oleh Departemen Kesehatan dan diselenggarakan oleh Dinas Kesehatan Provinsi atau Kota yang terkait. Hasil penelitian ini menunjukkan ketidaksesuaian dengan Permenkes nomor 942 tahun 2003.

Berdasarkan hasil kategorisasi skor praktik pedagang jajanan kue lapis menunjukkan bahwa praktik pedagang jajanan kue lapis tidak berada pada kategori baik $(0,0 \%)$, melainkan masuk dalam kategori sedang $(93,1 \%)$, dan kategori kurang $(6,9 \%)$. Dari hasil kategori tersebut dapat dilihat bahwa sebagian besar praktik personal hygiene pedagang berada pada kategori sedang. Penjamah makanan merupakan orang yang secara langsung berkaitan dengan proses makanan dari awal hingga akhir. Penelitian yang dilakukan oleh Setyorini (2013) menemukan sebesar 46,2\% pedagang telah memiliki praktik hygiene yang baik dan 53,8\% memiliki praktik hygiene yang kurang baik. Namun penelitian ini menunjukkan sebagian besar praktik personal hygiene pedagang termasuk dalam kategori sedang, hanya beberapa pedagang yang memiliki praktik personal hygiene yang kurang. Data karakteristik responden dapat dilihat pada Tabel 1 .

Hasil oberservasi terhadap praktik pedagang jajanan kue lapis menunjukkan bahwa sebagian besar pedagang mencuci tangan sebelum menjamah jajanan $(96,6 \%)$, kuku tangan pedagang yang bersih dan pendek $(86,2 \%)$, tidak menggunakan celemek (100\%), menggunakan pakaian bersih $(100 \%)$, berbicara saat menjamah makanan $(100 \%)$, tidak menggunakan alat bantu menjamah makanan (100\%), tidak menggunakan perhiasan saat menjamah makanan (37,9\%). Penelitian Agustina, dkk. (2012) menyatakan bahwa selama pengamatan tidak ditemui penjamah makanan

Tabel 1. Karakteristik Responden

\begin{tabular}{lcc}
\hline \multirow{2}{*}{ Karakteristik responden } & \multicolumn{2}{c}{ Frekuensi } \\
\cline { 2 - 3 } & $\mathbf{n}$ & $\mathbf{\%}$ \\
\hline Jenis kelamin & 8 & 72,4 \\
$\quad$ Laki-laki & 21 & 27,6 \\
$\quad$ Perempuan & & \\
Usia(tahun) & 5 & 17,2 \\
$26-35$ & 20 & 69,0 \\
$36-45$ & 3 & 10,3 \\
$46-55$ & 1 & 3,4 \\
56-55 & & \\
Tingkat Pendidikan & 15 & 51,7 \\
Tinggi ( $\geq$ SMA) & 14 & 48,3 \\
$\quad$ Rendah (< SMA) & & \\
Kepemilikan Sertifikasi & & \\
Penjamah Makanan & 0 & 0,0 \\
$\quad$ Memiliki & 29 & 100,0 \\
$\quad$ Tidak Memiliki & & \\
\hline
\end{tabular}


yang menggunakan celemek dan $69,6 \%$ tidak menggunakan alat bantu saat menjamah makanan. Responden yang tidak menggunakan alat bantu selama berdagang menyebabkan terjadinya kontak antara tangan pedagang dengan jajanan kue lapis. Berdasarkan hasil pengamatan, sebagian besar pedagang makanan jajanan telah mencuci tangan sebelum menjamah makanan. Menurut penelitian yang dilakukan Lambrechts, dkk. (2014), tangan penjamah makanan sebagai vektor penyebaran penyakit bawaan makanan sehingga perlu personal hygiene yang baik agar dapat menghasilkan mutu pangan yang baik pula.

Hal ini sesuai dengan penelitian yang dilakukan oleh Rachmawati, dkk. (2015) di Kota Jember yang menyatakan bahwa $83,3 \%$ penjamah makanan memiliki kebiasaan mencuci tangan yang baik dan $16,7 \%$ yang memiliki kebiasaan mencuci tangan buruk. Kegiatan mencuci tangan dengan sabun sebelum menjamah makanan menjadi salah satu cara untuk mencegah kontaminasi bakteri Escherichia coli yang kemudian dapat menimbulkan infeksi bila masuk ke dalam tubuh (CDC, 2016). Berdasarkan penelitian Puspita, dkk. (2013), kebiasaan mencuci tangan sebelum menjamah jajanan dapat memperkecil risiko terjadinya kontaminasi bakteri dari tangan ke makanan.

Hasil pemeriksaan keberadaan bakteri Escherichia coli pada kue lapis menunjukkan bahwa 55,2\% yang memenuhi syarat atau tidak ditemukan bakteri Escherichia coli dan 44,8\% yang tidak memenuhi syarat atau ditemukan bakteri Escherichia coli. Permenkes Nomor 1096 Tahun 2011 menyatakan bahwa bakteri Escherichia coli digunakan dalam penilaian hygiene sanitasi dimana jumlah dalam makanan harus nol. Berdasarkan hasil penelitian ini, hampir separuh jajanan kue lapis ditemukan bakteri Escherichia coli pada saat dilakukan uji laboratorium $(44,8 \%)$ dan sisanya tidak mengandung bakteri Escherichia $\operatorname{coli}(55,2 \%)$.

Hasil penelitian tersebut sesuai dengan beberapa penelitian sebelumnya yakni penelitian yang dilakukan oleh Pratiwi (2014) menunjukkan jajanan pasar kue cucur yang memenuhi syarat sebanyak $67 \%$. Selanjutnya penelitian yang dilakukan oleh Falamy, dkk. (2013) di Bandar
Tabel 2. Distribusi Perilaku Personal Hygiene Responden

\begin{tabular}{|c|c|c|}
\hline \multirow{2}{*}{ Variabel } & \multicolumn{2}{|c|}{ Frekuensi } \\
\hline & $\mathbf{n}$ & $\%$ \\
\hline \multicolumn{3}{|c|}{$\begin{array}{l}\text { Cuci tangan saat menjamah } \\
\text { makanan }\end{array}$} \\
\hline Ya & 28 & 96,6 \\
\hline Tidak & 1 & 3,4 \\
\hline \multicolumn{3}{|c|}{$\begin{array}{l}\text { Kuku tangan bersih dan } \\
\text { pendek }\end{array}$} \\
\hline Ya & 25 & 86,2 \\
\hline Tidak & 4 & 13,8 \\
\hline \multicolumn{3}{|c|}{ Menggunakan celemek } \\
\hline Ya & 0 & 0,0 \\
\hline Tidak & 29 & 100,0 \\
\hline \multicolumn{3}{|l|}{ Pakaian bersih } \\
\hline Ya & 29 & 100,0 \\
\hline Tidak & 0 & 0,0 \\
\hline \multicolumn{3}{|l|}{$\begin{array}{l}\text { Tidak berbicara saat } \\
\text { menjamah makanan }\end{array}$} \\
\hline Ya & 0 & 0,0 \\
\hline Tidak & 29 & 100,0 \\
\hline \multicolumn{3}{|l|}{$\begin{array}{l}\text { Tidak merokok saat } \\
\text { menjamah makanan }\end{array}$} \\
\hline Ya & 24 & 82,8 \\
\hline Tidak & 5 & 17,2 \\
\hline \multicolumn{3}{|c|}{$\begin{array}{l}\text { Menggunakan alat bantu saat } \\
\text { menjamah makanan }\end{array}$} \\
\hline Ya & 0 & 0,0 \\
\hline Tidak & 29 & 100,0 \\
\hline \multicolumn{3}{|c|}{$\begin{array}{l}\text { Menggunakan perhiasan saat } \\
\text { menjamah makanan }\end{array}$} \\
\hline Ya & 18 & 62,1 \\
\hline Tidak & 11 & 37,9 \\
\hline \multicolumn{3}{|c|}{ Praktik personal hygiene } \\
\hline Baik & 0 & 0,0 \\
\hline Sedang & 27 & 93,1 \\
\hline Kurang & 2 & 6,9 \\
\hline
\end{tabular}

Tabel 3. Distribusi Keberadaan Bakteri Escherichia coli

\begin{tabular}{lcc}
\hline Keberadaan Bakteri & \multicolumn{2}{c}{ Frekuensi } \\
\cline { 2 - 3 } \multicolumn{1}{c}{ Escherchia coli } & $\mathbf{n}$ & $\mathbf{\%}$ \\
\hline Ada & 13 & 44,8 \\
Tidak ada & 16 & 55,2 \\
\hline
\end{tabular}

Lampung juga menemukan bakteri Escherichia coli pada 4 sampel jajanan pasar cincau hitam di pasar tradisional dan swalayan kota Bandar Lampung. Penelitian yang dilakukan oleh Gobel (2013) menemukan kue lapis yang dijual di Pasar Sentral Kota Gorontalo tidak memenuhi syarat karena memiliki angka cemaran mikroba yang melebihi standar yang ditetapkan. Hal yang sama juga ditemukan dalam penelitian yang dilakukan oleh Sofiana (2012) bahwa makanan 
jajanan di Sekolah Dasar Kecamatan Tapos Depok yang terkontaminasi bakteri Escherichia coli sebanyak 44,1\%. Adanya kuman Escherichia coli dalam makanan menandakan bahwa makanan jajanan tersebut tercemar dan tidak aman untuk dikonsumsi.

Tabel 4 menunjukkan bahwa pada kelompok pedagang dengan perilaku sedang hampir sebagian besar $(44,4 \%)$ jajanan kue lapis yang dijual mengandung Escherichia coli. Hasil analisis menggunakan uji Chi-Square dengan tingkat signifikansi 5\% terhadap hubungan antara perilaku personal hygiene pedagang dengan keberadaan bakteri Escherichia coli diperoleh nilai p sebesar 0,879 yang menunjukkan bahwa tidak terdapat hubungan antara praktik personal hygiene pedagang dengan keberadaan bakteri Eshcerichia coli pada jajanan kue lapis yang dijual pedagang.

Penelitian ini sesuai dengan penelitian yang dilakukan oleh Sofiana (2012) di Kecamatan Tapos Depok yang menunjukkan bahwa tidak adanya hubungan antara praktik penjamah makanan dengan kontaminasi bakteri Escherichia coli. Berdasarkan hasil penelitian Kurniasih, dkk. (2015) di Magelang juga menunjukkan tidak terdapat hubungan antara praktik personal hygiene pedagang dengan kontaminasi Escherichia coli. Hal ini dapat disebabkan karena sebagian besar pedagang telah melakukan praktik personal hygiene dengan cukup baik.

Meski tidak ada hubungan namun adanya bakteri Escherichia coli dalam jajanan kue lapis dapat disebabkan oleh beberapa faktor yang terdiri dari peralatan yang digunakan, bahan makanan, dan sarana penjualan. Peralatan makanan pedagang yang tidak memenuhi syarat berisiko 4,5 kali lebih besar mengandung Escherichia coli dibandingkan dengan peralatan pedagang yang memenuhi syarat (Riyanto dan Abdillah, 2012).
Sanitasi alat yang digunakan produsen dapat menjadi salah satu faktor adanya Escherichia coli dalam jajanan. Berdasarkan penelitian yang dilakukan oleh Sofiana (2012) menunjukkan bahwa sanitasi alat memiliki pengaruh terhadap tingkat kontaminasi Escherichia coli. Berdasarkan hasil wawancara mendalam, sebagian besar pedagang bukan merupakan pembuat kue lapis yang dijual. Pedagang mengambil kue lapis dari produsen atau produsen yang mengantarkan kepada pedagang dalam wadah plastik yang tidak tertutup rapat. Selain itu, berdasarkan hasil observasi, lingkungan dimana pedagang berjualan juga kurang bersih. Sarana penjualan yang terbuka, tidak terlindung dapat memudahkan debu dan serangga seperti lalat, yang berpotensi membawa bakteri patogen, untuk mengontaminasi jajanan (Samapundo, dkk., 2016). Faktor produsen jajanan kue lapis, sanitasi makanan yang kurang baik dan lingkungan yang kurang bersih berpotensi sebagai media penyebaran karena bakteri Escherichia coli mengkontaminasi makanan melalui air maupun lingkungan yang kurang bersih. Jajanan yang kontak langsung dengan air maupun lingkungan yang tercemar jika ditemukan bakteri Escherichia coli melalui uji laboratorium, maka diindikasikan bahwa jajanan tersebut pernah terkontaminasi kotoran manusia (Falamy, dkk., 2013).

\section{KESIMPULAN DAN SARAN}

Penelitian ini menyimpulkan bahwa tidak terdapat hubungan antara perilaku personal hygiene pedagang dengan keberadaan bakteri Escherichia coli pada jajanan kue lapis yang dijual di Pasar Kembang Kota Surabaya. Hampir separuh kue lapis yang dijual di Pasar Kembang Kota Surabaya mengandung bakteri Escherichia coli sehingga dibutuhkan upaya untuk menanggulangi masalah

Tabel 4. Analisis Hubungan Perilaku Personal Hygiene Pedagang dengan Keberadaan Bakteri Escherichia coli

\begin{tabular}{|c|c|c|c|c|c|c|c|}
\hline \multirow{3}{*}{$\begin{array}{c}\text { Perilaku Penjamah } \\
\text { Makanan }\end{array}$} & \multicolumn{4}{|c|}{ Hasil Uji Escherichia coli } & \multirow{2}{*}{\multicolumn{2}{|c|}{ Total }} & \multirow{3}{*}{$p$ value } \\
\hline & \multicolumn{2}{|c|}{ Ya } & \multicolumn{2}{|c|}{ Tidak } & & & \\
\hline & $\mathbf{n}$ & $\%$ & n & $\%$ & $\mathbf{n}$ & $\%$ & \\
\hline Baik & 0 & 0,0 & 0 & 0,0 & 0 & 0,0 & \\
\hline Sedang & 12 & 44,4 & 15 & 55,6 & 27 & 100,0 & 0,879 \\
\hline Kurang & 1 & 50,0 & 1 & 50,0 & 2 & 100,0 & \\
\hline
\end{tabular}


tersebut antara lain dengan menjaga kebersihan lingkungan tempat penjualan dan sanitasi alat yang digunakan produsen serta menggunakan tempat penyimpanan yang tertutup rapat saat melakukan pengiriman kue lapis.

\section{DAFTAR PUSTAKA}

Agustina, F., Pambayun, R., \& Febry, F. (2012). Higiene dan sanitasi pada pedagang makanan jajanan tradisional di lingkungan Sekolah Dasar di Kelurahan Demang Lebar Daun Palembang Tahun 2009. Diakses dari http:// eprints.unsri.ac.id/64/

Badan Pengawas Obat dan Makanan (2015). Berita keracunan bulan Januari-Maret 2015. Diakses dari http:/ik.pom.go.id/v2014/berita-keracunan/ berita-keracunan-bulan-januari-maret-2015.

Centers for Disease Control and Prevention [CDC]. (2016). E. Coli (Escherichia coli) general information. Diakses dari http://www.cdc.gov/ ecoli/general/index.html.

Falamy, R., Warganegara, E., \& Apriliana, E. (2013). Deteksi bakteri coliform pada jajanan pasar cincau hitam di pasar tradisional dan swalayan Kota Bandar Lampung. MAJORITY (Medical Journal of Lampung University), 2(5), 1-9. Diakses dari ejournal.unila.ac.id.

Food and Agriculture Organizations. (2009). Street food. Diakses dari http://www.fao.org/fcit/foodprocessing/street-foods/en/.

Gobel, G. (2013). Uji kandungan rhodamine B dan keberadaan bakteri padajajanan kue berwarna yang ada di pasar sentral Kota Gorontalo Tahun 2013. (Skripsi yang tidak dipublikasikan). Universitas Negeri Gorontalo, Gorontalo. Diakses dari http://kim.ung.ac.id/index.php/ KIMFIKK/article/download/2748/2724.

Kurniasih, R.P., Nurjazuli, \& Hanani, Y. (2015). Hubungan higiene dan sanitasi warung makan dengan kontaminasi bakteri Escherichia coli dalam makanan di warung makan sekitar Terminal Borobudur Magelang. Jurnal Kesehatan Masyarakat, 3(1), 549-558. Diakses dari http://ejournal-s1.undip.ac.id/index.php/ $\mathrm{jkm}$.

Lambrechts, A.A., Human, I.S., Doughari, J.H., \& Lues, J.F.R. (2014). Bacterial contamination of the hands of food handlers as indicator of hand washing efficacy in some convenient food industries. Pakistan Journal of Medical Sciences, 30(4), 755-758. Diakses dari http:// www.pjms.com.pk/index.php/pjms/article/ view/4400/2552.

Latudi, R. (2012). Aspek hygiene dan sanitasi makanan di pasar jajan Kota Gorontalo Tahun 2012. (Skripsi yang tidak dipublikasikan). Universitas Negeri Gorontalo, Gorontalo. Diakses dari http://eprints.ung.ac.id/5913/5/2012-113201-811408086-bab2-14082012102759. pdf.

Menteri Kesehatan (2011). Keputusan Menteri Kesehatan Republik Indonesia Nomor 1096/ Menkes/Per/VI/2011 tentang hygiene sanitasi jasaboga. Diakses dari http://pelayanan.jakarta. go.id/download/regulasi/permen-kesehatannomor-1096-menkes-per-vi-2011-tentanghigiene-sanitasi-jasaboga.pdf.

Makalew, L. (2014). Hubungan hygiene sanitasi dan perilaku penjamah kue dengan keberadaan bakteri Escerichia coli pada kue popaco di pasar sentral Kota Gorontalo Tahun 2013. (Tesis yang tidak dipublikasikan). Universitas Negeri Gorontalo, Gorontalo. Diakses dari http:// kim.ung.ac.id/index.php/KIMFIKK/article/ download/2721/2697.

Menteri Kesehatan (2003). Peraturan Menteri Kesehatan RI Nomor 942/Menkes/SK/V/2003 tentang pedoman persyaratan hygiene dan sanitasi makanan jajanan. Diakses dari http:// dinkes.surabaya.go.id/portal/files/kepmenkes/ Kepmenkes\%20942-MENKES-SK-VII-2003Makanan\%20Jajanan.pdf.

Mohede, M., \& Saptorini, K.K. (2015). Keberadaan bakteri Escherichia coli pada sambal makanan akibat higiene penjual yang kurang baik. Jurnal Visikes, 14(1),10-16. Diakses dari http:// publikasi.dinus.ac.id/index.php/visikes/article/ view/1157/867

Notoadmodjo, S. (2011). Kesehatan masyarakat: Ilmu \& seni. Jakarta: PT. Rineka Cipta.

Pratiwi, D. (2014). Hygiene sanitasi pedagang kue dan keberadaan Escherichia coli pada makanan jajanan kue cucur di wilayah pasar tradisional Desa Kaliyoso Kecamatan Bongomeme Kabupaten Gorontalo Tahun 2012. (Tesis yang tidak dipublikasikan). Universitas Negeri Gorontalo, Gorontalo. Diakses http://eprints. ung.ac.id/6383/

Puspita, I., Palandeng, H., \& Sinolungan, J. (2013). Hubungan praktik higiene sanitasi penjamah makanan terhadap cemaran Escherichia coli pada makanan gado-gado di sepanjang jalan Kota Manado. Diakses dari http://fkm.unsrat. 
ac.id/wp-content/uploads/2013/08/JURNAL Ika-Puspita-091511171-Kesling.pdf .

Rachmawati, R., Ningrum, P.T., \& Pujiati, R.S. (2015). Praktik higiene personal dan keberadaan bakteri Escherichia coli pada tangan penjamah makanan (studi pada pedagang kaki lima di jalan Kalimantan Kecamantan Sumbersari Kabupaten Jember) (Artikel ilmiah, Universitas Jember, Jember). Diakses dari http://repository. unej.ac.id/bitstream/handle/123456789/72293/ Roidatu\%20Rachmawati.pdf?sequence=1 .

Riyanto, A., \& Abdillah, A.D. (2012). Faktor yang mempengaruhi kandungan E. coli makanan jajanan SD di wilayah Cimahi Selatan. Majalah Kedokteran Bandung, 44(2), 77-82. Diakses dari http://journal.fk.unpad.ac.id/index.php/ $\mathrm{mkb} /$ article/viewFile/127/pdf 33.

Samapundo, S., Cam Thanh, T.N., Xhaferi, R., \& Devlieghere, F. (2016). Food safety knowledge, attitudes, and practices of street food vendors and consumers in Ho Minh city, Vietnam. Food Control, 70, 79-89. Diakses dari http:// www.sciencedirect.com/science/article/pii/ S0956713516302717

Setyorini, E. (2013). Hubungan praktek higiene pedagang dengan keberadaan Escherichia coli pada rujak yang di jual di sekitar kampus Universitas Negeri Semarang. Unnes Journal of Public Health, 2(3), 1-8. Diakses dari http://journal.unnes.ac.id/artikel_sju/pdf/ ujph/3025/2798

Sofiana, E. (2012). Hubungan higiene dan sanitasi dengan kontaminasi Escherichia coli pada jajanan Sekolah Dasar Kecamatan Tapos Depok Tahun 2012. (Skripsi yang tidak dipublikasikan). Universitas Indonesia, Depok. Diakses dari http://lib.ui.ac.id/file?file=digital/20319719-SPDF-Erna\%20Sofiana.pdf 